\title{
The Moral Challenges of Female Genital Mutilation on the Stability of Marriage in Ebonyi State
}

\author{
Chidimma Stella Ikea1, Nneoma Christiana Onuh'², Augustine U. Emela ${ }^{2}$ \\ ${ }^{1}$ Department of Philosophy, Imo State University, Owerri, Nigeria \\ ${ }^{2}$ Department of English and Literary Studies, Imo State University, Owerri, Nigeria \\ Email:mmaimsu@gmail.com
}

How to cite this paper: Ikea, C. S., Onuh, N. C., \& Emela, A. U. (2021). The Moral Challenges of Female Genital Mutilation on the Stability of Marriage in Ebonyi State. Open Journal of Philosophy, 11, 59-74. https://doi.org/10.4236/ojpp.2021.111006

Received: November 19, 2020

Accepted: January 29, 2021

Published: February 1, 2021

Copyright $\odot 2021$ by author(s) and Scientific Research Publishing Inc. This work is licensed under the Creative Commons Attribution International License (CC BY 4.0).

http://creativecommons.org/licenses/by/4.0/

\begin{abstract}
Many cultures, in Nigeria today, are emerging from very traditional arcane cultural practices and are embracing more egalitarian and emancipatory values, especially for women. One of the cultural practices that have come under intense scrutiny in the treatment of women and the girl-child is the practice of Female Genital Mutilation or Cutting (FGM/C). It is one of the widely and deep-rooted cultural practices in Nigeria, especially in Ebonyi State. The aim of this paper is to examine the morality of female genital mutilation and its effect on the stability of marriages in Ebonyi state. The questions become, what is female genital mutilation? Is the practice morally justified and acceptable? Does it abuse the fundamental right of the woman? How does it affect the stability of marriages? These questions and many of its kinds surround the cultural practices of Female Genital Mutilation. This work is a contribution to the body of qualitative research, which explores the morality and effect of female genital mutilation on the stability of marriages, in Ebonyi state. The researchers contend that female genital mutilation (FGM) has a negative impact on the sexual life for women and therefore impacts negatively on their marriage. Using the moral prism and spectacles of virtue ethics and human right theories to examine the cultural practice of FGM, it therefore concludes that it should be discouraged because it violates women's rights to life, physical integrity, good health and social flourishing.
\end{abstract}

\section{Keywords}

Female Genital Mutilation, Women, Marriage, Morality, Human Dignity

\section{Introduction}

Female genital mutilation/cutting (FGM/C), also popularly known as female 
circumcision (FC) is one of the issues that have attracted much attention across the globe. It is defined as "all procedures involving partial or total removal of the external female genitalia or the female genital organs whether for cultural or other non-therapeutic reasons." In other words, it is the collective name given to several different traditional practices that involve the cutting of female genitals.

The WHO (World Health Organization, 1999) classifies FGM/C into four major types: Type I (Clitoridectomy) is partial or total removal of the clitoris (the small, sensitive, erectile part of the female genitals) and, in very rare cases, only the prepuce, i.e. the fold of skin surrounding the clitoris. Type II (Excision) involves partial or total removal of the clitoris and labia minora, with or without excision of the labia majora (the labia are the "lips" surrounding the vagina). Type III (Infibulation), the most severe form of FGM, narrows the vaginal opening through a covering seal formed by cutting and repositioning the inner or outer labia, with or without removal of the clitoris. The wound edges are repositioned by stitching or holding the cut areas together for a period of time (for example, girls' legs are bound together), to create the covering seal; a small opening is left for urine and menstrual blood to escape. Type IV includes all other harmful procedures to female genitalia for non-medical purposes, including pricking, piercing or incising the clitoris or labia; stretching the clitoris or labia; cauterization by burning the clitoris and surrounding tissue; scraping tissue surrounding the vaginal orifice or cutting the vagina; introducing corrosive substances or herbs into the vagina, to cause bleeding for tightening or narrowing it.

The motives for FGM are complex and vary between different contexts and across times. Hence, there are heated international debates surrounding the practice of FGM, because of the health risks associated with the different procedures; and the psychological and social trauma it tends to introduce in the social life of women who are forced to go through with it.

This paper shall be laid out in 2 parts. Part I shall be a presentation of the research done in Ebonyi State of Nigeria on FGM. It will explore the problematics of FGM, Objectives of the Study, Literature Review and examination of the survey data. Part II is a qualitative analysis that discusses the moral implications of FGM. Using the moral principles of human rights, harm and bodily integrity, it exposes the negative effects of FGM and concludes that given the nature of its attendant psycho-physical complications for the development of the female child, FGM is morally obnoxious and cannot be good for the stability of marriage in Ebonyi state and indeed elsewhere.

\section{Statement of Problem of Female Genital Mutilation}

FGM is recognized and practiced in many Nigerian cultures (especially in Ebonyi state), and it is considered an important rite of passage for women's socialization, curbing their sexual appetite, and prepares them for marriage. In other words, it is believed that for any lady to accepted as parts and parcel of the society, to be marriageable in the society, must pass through female genital mutilation. 
The ironical aspect of this rite of passage, is that, as it is intended to make women marriageable, yet it leads to difficulties, causes more harm than good to the supposed "wife material", by exposing her to physical pains as well as psychological shock, trauma, sexual complications and sociological manipulations and oppression (Andarge, 2014). This work therefore looks at the moral challenges of female genital mutilation on the stability of marriage in Ebonyi State.

\section{Objective(s) of the Study}

The objective of this research is to investigate and discover the morality of female genital mutilation (FGM) and its effects on the stability of marriages in Ebonyi state. In other words, it is to ascertain the effect and implication of FGM/C for social work practice in Ebonyi state and to determine if there are differences between those who believe that FGM exists and those who do not believe its existence.

It intends to find out if religion has a role to play in the promotion or otherwise of FGM and as well as find out other factors that may influence the existence of FGM. The community enforcement mechanisms identify FGM as an instrument of social conformity, an integral part of community festival activities and community identity. Enforcers are mostly women, primarily mothers (especially those who were cut) and aunts, as well as highly respected women in the communities, including traditional birth attendants (TBAs), local barbers, medical doctors, and health workers. In some communities, enforcement mechanisms include promises of rewards; emotional manipulation and outright misinformation, [such as that it prevents promiscuity, "makes a girl a good wife" and aids in smoother delivery during child birth].

\section{Literature Review}

The issue of Female Genital Mutilation (FGM) has attracted considerable attention in recent times and debates have taken place as to the best way to refer to this practice. The phrase female genital mutilation could be interpreted by some as a value loaded term that labels women as mutilated, when they may not in fact see themselves as having undergone a process of "mutilation" per se. The use of the term mutilation is thought to imply excessive judgement by outsiders and insensitivity toward individuals who have undergone the procedure. Women may be more accepting of the term "cutting" as a less stigmatizing way of describing the practice.

Ivana Hrvatin and Darija Šćepanović (2018) explain that female genital mutilation (FGM) refers to all procedures involving partial or total removal of the external female genitalia, or other injuries to the female genital organs for non-medical reasons.

The practice of FGM is thought to date back to the fifth century B.C. In Africa, reports reveal that in 28 to 30 countries this procedure is performed (Okeke, Anyaehie, \& Ezeanyeaka, 2018), ranging from nearly 90 per cent or higher in Egypt, Eritrea, Mali and Sudan, to less than 50 per cent in the Central African 
Republic and Cote d'Ivoire, to 5 per cent in the Democratic Republic of Congo and Nigeria. In African countries that practice FGM, anywhere from 50\%-90\% of the women are mutilated. In Islamic countries in both Asia and the Middle East, the Arabian Peninsula, and the Persian Gulf, the practice is also seen in. Evidence suggests that FGM is practiced in parts of South America, in the southern part of. The practice is also found in parts of Europe, Australia and North America, due to immigration and displacement caused by civil wars, globalization and migration. Therefore, FGM is a global concern.

However, UNICEF estimates that approximately 135 million women and girls have undergone FGM/C, with 3 million girls and women remaining at risk of the procedure each year. It is also calculated that 100,000 women and teenagers die from complications related to FGM/C in childbirth per annum. Female Genital Mutilation/Cutting is known to be performed in at least 28 African, Middle Eastern and Asian countries (Okeke, et al., 2018).

In most cases, the procedure is performed on young females, usually between the age of five and twelve, yet there have been reported cases of FGM performed on even younger females. Due to the clandestine nature of the ritual, the child has little to no knowledge of what awaits her prior to the procedure. In fact, she may be treated differently prior to the initiating event. Several articles reference the notion that these "soon-to-be-women" are treated like royalty, given gifts and observe the culminating event with a celebration. In its entirety, the procedure lasts anywhere from 20 - 30 minutes, although some sources cite less. In most cases analgesia is not commonly used while the excisor uses blessed knives, razor blades or broken glass during the mini surgery. In most cases these instruments are not sterilized between surgeries. A lack in sterilization is likely one of the many culprits contributing to the increase in HIV/AIDs and other infectious diseases among African natives.

According to Little (2003); the procedure is typically performed by a midwife, a trained elderly woman or a traditional healer. While Berggren, et al. (2006), note that the FGM procedure is carried out in remote areas as well as in cities and at all levels of society, from the elite and professional classes to the simplest villager. In rural areas older women who are known as traditional "cutters" perform FGM. Crude instruments such as knives, razors, scissors or sharp stones are often used. It is likely to be performed under unhygienic conditions with the same instruments used on different girls. In urban areas the procedure is more likely to be performed under anesthesia, with some health workers believing that this makes the procedure more acceptable. In this case the term medicalization of FGM is used and refers to situations in which FGM is practiced by health-care providers, whether in a public or private clinic, at home or elsewhere.

The true purpose of FGM is to keep women under absolute male control, and may also be used to limit female actions that may reflect negatively on the family. Still, it is important to keep in mind that this act is not done to the female but rather for the female. There are five major premises behind FGM; they are 1) so- 
ciological, 2) sexual, 3) aesthetic, 4) health, and 5) religious reasons for having FGM. Deeply rooted in a cultural context, FGM has become an integrated way to seek and maintain identity and ultimately social control and approval. From the introduction, the concept of clans was presented. With that, FGM is often sought after as another means to conform to society and or to maintain social cohesion. Female genital mutilation is a deeply embedded cultural tradition that holds a symbolic meaning in numerous communities. The continued practice of FGM is motivated by peer pressure, fear of exclusion from resources and opportunities for young women. The traditional motivation is very strong, as this is the main reason women let their children undergo FGM (Mberu, 2018). Other reasons for FGM are cultural group identity, family honour, cleanliness and health, preservation of virginity and enhancement of sexual pleasure for men. The belief that FGM is required for spiritual and religious cleanliness is also a strong motivational factor.

The role that women play in this practice is also strengthened by the ritual aspect of FGM. Though performed in private, the occurrence of this practice in some communities is marked with a ceremony celebrating the girls' transition to womanhood. It is therefore also seen as the key "rite of passage" in women's lives, and, in this sense, some communities see FGM as a way of strengthening the social bonds between women (Ossai, E et al., 2018).

Lastly, although FGM is also sometimes believed to be linked to religious beliefs, it is actually practiced across religions, and there are no identified religious justifications or origins for the maintenance of the practice. Although Muslims are the most likely religious group to practice FGM, a basis for continuing the practice is not found in the Koran. Religious leaders have denounced the continuance of the practice but the belief in its religious origins remains widespread immediate effects of FGM. The immediate, short-term problems faced by women are death, the threat of death from hemorrhaging, and shock from the pain and level of violence associated with carrying out the procedure. Long term effects of FGM frequent urinary tract infections, urinary retention and abscess formation, septicemia, increased pain during menstruation, with related buildup of menstrual fluid as time passes, and the development of scar tissue are some of the documented long-term side effects of the procedure (Yoder \& Khan, 2008).

\section{Methodology of the Study}

\section{Study area}

The study area is on female genital mutilation and the research is carried out in Ebonyi state, Nigeria.

\section{Procedure}

The study design is descriptive, explorative and investigative. It also involves a systematic review of literature, from conference papers, journal articles, questionnaire, textbooks and internet articles.

Data Analysis/ Discussion 
Primarily, two focal groups were arranged, that is, men and women. This was done to obtain more in-depth insight into the issue of FGM. This was designed to know whether men and women have different concepts or ideas about FGM. The questionnaires were then given to the respondents, based on their ages, educational background, marital status and experiences. Some of the respondents to the questionnaires were married, divorced, unmarried, retired, employed, civil servants, unemployed and self-employed people. The questionnaires were given to different people from different works of life, from different areas of Ebonyi state, both rural and urban where FGM is prevalent. In other words, the questionnaires were designed in a simple way to include multiple choice questions and binary "yes/no" answers. It equally has "don't know and others", where participants could add individual comments. Two thousand (2000) questionnaires were given to the respondents and 820 people responded to the questionnaires anonymously.

\begin{tabular}{ccc}
\hline $\begin{array}{c}\text { People } \\
\text { Men and women issued } \\
\text { Questionnaire }\end{array}$ & $\begin{array}{c}\text { Total number of } \\
\text { respondents } \\
820\end{array}$ & $\begin{array}{c}\text { Percentage number } \\
\text { of respondents. } \\
100 \%\end{array}$ \\
\hline $\begin{array}{c}\text { People who are not aware } \\
\text { of the negative effects of FGM/C } \\
\text { People who are aware } \\
\text { of the negative effects of FGM/C }\end{array}$ & 205 & $25 \%$ \\
\hline
\end{tabular}

\section{Discussions: Implications for Marital Wellbeing in Ebonyi State}

From the table above, 205 out of the 820 people or $25 \%$ of the respondents were not aware of the negative effects of FGM. Some of them who added their comments viewed FGM as a source of pride and sense of belonging, as well as a rite of passage and an integral part of culture, especially for marital stability and overall welfare of the family. This group viewed it as socio-cultural feature in the family and good of the society.

FGM may also be a rite of passage from childhood to womanhood. Another possible reason is fear of sexual violence against girls, as FGM precludes vaginal penetration (WHO, 2011). FGM is sustained by community enforcement mechanisms such as public recognition by celebration (use of rewards and gifts, poems and songs celebrating the circumcised while deriding the uncircumcised), the refusal to marry uncircumcised women and fear of punishment by God. Mothers may subject daughters to FGM to protect them, to secure good prospects of marriage, to ensure acceptance and for economic security. Even though no religious text requires FGM, there is a strong belief of its requirement by some local religious leaders. The practice predates both Christianity and Islam and is unknown in many Muslim countries. In Egypt, Sudan and Senegal, Christian and Muslim religious leaders condemned the practice, declared it violates women's dignity, and have been promoting the uncut girl as happy and healthy, 
thus helping to abandon the practice (Ukhun, 2002).

On the other hand, 615 of the 820 people or $75 \%$ of the respondents were aware of the negative effects of FGM. From their responses and reactions, there is a high opinion against the practice of FGM. In other words, many respondents, especially the married, (divorced) and educated ones were against the practice of FGM. They view it as an immoral and harmful practice that should not be encouraged. To them, FGM has no health benefit, hence harms both girls and women by portending the following negative effects: Physical Pain, Psychological Trauma, Exposure to Infections and Inhibition of Sexual Satisfaction. There is also danger of infection, infertility, and even death.

\section{1) Severe Physical Pain and even Death}

Female Genital Mutilation causes severe pains and shock. The cutting of the nerve ends and sensitive genital tissue causes excruciating pain, and it can result in mental and psychological trauma. Women have been taught that this painful and dangerous acts are important for their health and beauty. Nawal el Saasawi (1970), an Egyptian writer, psychiatrist and co-founder of the African Women's Association for Research and Development, narrates her experience at the age of six, when she was taken from her bed and carried into the bathroom for the amputation of her clitoris:

I was frightened and ... there were many of them ... and something like an iron grasp caught hold of my hand and my arms and my thighs, so that I became unable to resist or even move .... Then suddenly the sharp metallic edge seemed to drop between my thighs and there cut off a piece of flesh from my body .... I screamed with pain ... for the pain was not just a pain, it was like a searing flame that went through my whole body.

This pain leads to shock. According to Crossette (1995), the medical consequences of genital mutilation can be serious. Pain is intense and can persist for years.

FGM can also lead to death. While discussing with one of the respondents, she recalled how her friend died in the process, because she lost a lot of blood. Frances A. Althaus (1997), explains that the practice of female circumcision is detrimental to women's health and well-being; it can cause death or permanent health problems due to infections, as such tetanus, hemorrhage etc. Hence:

Female circumcision can lead to potentially fatal complications, such as hemorrhage, infection and shock. The inability to pass urine because of pain, swelling and inflammation following the operation may lead to urinary tract infection. A woman may suffer from abscesses and pain from damaged nerve endings long after the initial wound has healed.

\section{2) Exposure to Infections}

Female Genital Mutilation causes menstrual, urinary and sexual problems/infection. According to Hillary Lips (2005) it can lead to complications, such as infection, shock, difficulties with menstruation and urination and painful intercourse. This is also as a result of the use of contaminated and unsterilized instruments. If the infections are not treated, can ascend to the kidneys, 
thereby, resulting in renal failure, septicaemia etc. In other words, it exposes them to danger, Hillary Lips explains:

If the infection from the procedure does not kill them, these girls may suffer for years from pelvic infections, caused by trapped urine or menstrual fluid. Their scarred birth canal create unnecessary dangers and agony each time they give birth; the baby's head may become trapped, leading to a hemorrhage or a ruptured fluid.

A. Z. Mustafa (1966) explains more:

Infibulation is particularly likely to cause long-term health problems. Because the urethral opening is covered, repeated urinary tract infections are common, and stones may form in the urethra and bladder because of obstruction and infection. If the opening is very small, menstrual flow may be blocked, leading to reproductive tract infections and lowered fertility or sterility. One early study estimated that $20 \%$ - $25 \%$ of cases of sterility can be linked to infibulation.

One may therefore wonder how such incidence of infection-induced sterility can bode well for marriage in Ebonyi State and elsewhere.

\section{3) Psychological Trauma and Inhibition of Sexual Satisfaction}

The Centre for Reproductive Right (2006) adds that the complications associated with FGM often have severe consequences for a woman's physical, emotional, psychological and mental health. But even in the absence of complications, where FGM results in the removal of bodily tissue necessary for the enjoyment of a satisfying and safe sex life, a woman's right to the "highest attainable standard of physical and mental health" has been compromised. Similarly, Fisaha (2016) asserts that;

Depending on what type of FGM is performed, the immediate health consequences of the procedure can include such complications as pain and bleeding that can lead to hemorrhage and even death. Long-term consequences can include irreversible loss of the clitoris, and possibly the outer and inner labia. Chronic infection, infertility, difficult pregnancy and childbirth, as well as painful sexual intercourse and menstruation are also common permanent effects of the procedure.

Based on the sexual control theory which suggests that female circumcision is practiced to weaken a woman's sexual desires, this type of sexual control renders women vulnerable to male domination. The practice is degrading to women, hence deprives them of self-dignity and sexuality. Jessica A. Platt, maintains that the practice of female circumcision is a form of torture, subjecting girls, ages two to fourteen, to a painful, unsanitary procedure that may cause infection or prevent childrearing. Francis Althaus (1997), adds:

The amputation of the clitoris and other sensitive tissue reduces a woman's ability to experience sexual pleasure. For infibulated women, the consummation of marriage is likely to be painful because of the small vaginal opening and the lack of elasticity in the scar tissue that forms it. Tearing and bleeding may occur, or the infibulation scar may have to be cut open to allow penetration. Infibulation may make intercourse unsatisfying for men as well as women. Under such 
conditions, marital dissolution may occur, especially if a woman's fertility is affected. infibulated women are almost twice as likely as other women to have lower fertility and more than twice as likely to be divorced.

So, for those who condone FGM based on cultural or religious values, women [they argue] desire circumcision to be marriageable, or for chastity, as well as for aesthetics purposes or to conform to tradition. Ironically, this particular practice that is justified as making girls marriageable and safeguarding their fertility actually increases the risk of marital dissolution, and infertility, because in the Nigerian culture where the children are valued [especially the male child] infertility is often blamed on the woman who may carry this stigma and may lead to her husband devaluing her, divorcing her and marrying another woman.

From the foregoing, it is clear that FGM therefore negatively affects the stability of marriages. The above effects make it evident that FGM, brings along very heavy collateral burdens to the family and marriage institution in Ebonyi state.

\section{Moral Burdens and Implications of FGM}

For proper analysis, FGM must be scrutinized with the prism of philosophical moral principles. Easily the moral principles [of health care ethics, within which domain FGM falls], that qualify to quickly confront FGM are these: Principles of Paternalism, Human Rights, Personal Integrity, and Avoidance of Harm, among others.

\section{The Moral Paternalism of FGM}

FGM is often justified under the principle of moral paternalism, which states that society is justified to interfere in the direction and control of women's sexual desires, to promote the moral well-being of the person (Igboanusi, 2009). The overall posture of practitioners of FGM rests on Paternalism [from the Latin; pater meaning "father"], whose social role is to provide resources and security for his family. Paternalistic attitudes rest on the assumptions that the individual in question is weak, or somehow incapable of controlling their sexual desires, hence the society [through the midwives and "cutters" as the "Father figure"] has to step in to provide guidance, resources or security.

The moral hinge or questionability of paternalism is the assumption it makes that the weak person does not have full faculties and therefore full rights. This situation therefore warrants the interference of the state or an individual, to make decisions for the weak person[s] against their will. It is justified by a claim that the person interfered with, will be better off or protected from harm (Igboanusi, 2009). However, $\mathrm{x}$-rayed under the other moral principles, paternalism is found to be very greatly deficient, especially as it can violate the very foundations of the person's bodily, spiritual and psychological integrity.

The paternalistic foundation for FGM rests also on the fact that performing FGM on girl children and women is also associated with culturally specific notions of femininity and beauty. The clitoris is believed to be the "masculine" part of the female genitalia, and fear surrounds its potential to grow bigger than the male reproductive organs (Lightfoot-Klein, 1989). Removal of the clitoris therefore asserts women's femininity through the enhancement of socially con- 
structed ideals of aesthetic beauty. Apart from these issues, linked to gender stereotyped perceptions of appropriate social and sexual behaviour, women, especially in developing countries, are also disadvantaged on many other levels relative to their male counterparts. They may be confined to the domestic realm, and as such are in a position of economic dependence that is transmitted through generations; prior to marriage they have to rely on their fathers for survival, and upon marriage, on their husbands. Where it is socially unacceptable for men to marry women who have not undergone FGM/C, women have very little choice but to abide by this practice. In fact, other women, mothers in particular, often advocate continuance of the procedure, in order to protect the future of their daughters. FGM/C is thus viewed as a method of protection of women, in that it is believed to guard women from pre-marital promiscuity, pre-marital pregnancy, and also as a protection of their future economic survival, minimizing the risk of absolute poverty, and social ostracism (Odimegwu, C, et al., 1998).

\section{Principle of Human Rights}

Basically, the principle of human rights "signifies that person's possess intrinsic worthiness and deserve unconditional respect, regardless of age, sex, health status, social or ethnic origin, political ideas, religion or criminal history. This respect is owed every individual by the mere fact that he or she is a 'member of the human family"' (Universal Declaration of Human rights, 1948, Preamble in Igboanusi, 2011).

Against the backdrop of this principle, FGM is one of the deep-rooted cultural practices that violate the right and dignity of womanhood. On account of the fact that it is often done without the proper and informed consent of the people involved, it expropriates their will and so constitutes a form of discrimination against women. Subjecting a person to health risks in the absence of medical necessity is a violation of that person's right to health. Hence FGM is a form of violence against women as well as human right infringement. According to the Centre for Reproductive Right (2006):

The rights to life and to physical integrity are considered core human rights ... FGM can be seen to violate the right to life in the rare cases in which death results from the procedure. The right to physical integrity, while often associated with the right to freedom from torture, encompasses a number of broader human rights principles, including the inherent dignity of the person, the right to liberty and security of the person, and the right to privacy. Acts of violence that threaten a person's safety, such as FGM, violate a person's right to physical integrity...

To Francis Althaus (1997), female circumcision a ritualized form of child abuse and violence against women, a violation of human rights. W Raspberry (1993) Considers FGM/C as "torture", an "atrocity," "barbarism" as well as "unconscionable child abuse," "a brutal, and savage practice".

Furthermore, John J. Macionis (2005), explains that in global perspective, violence against women is built into culture in other ways. One case in point is the 
practice of female genital mutilation, a painful surgical procedure. Hillary Lips (2003:99), adds that it is an invasive, painful and dangerous operation, while Jessica A. Platt, regards female genital mutilation is considered a human tragedy, an abuse. This harmful practice of removing and injuring healthy and normal female genital tissues, interfering with the natural functions of the girls'/womens' bodies. Hence:

All forms of FGM are associated with increased health risk. It is a harmful practice and is unacceptable from the human rights as well as a public health perspective, regardless of who performs it. (WHO, Health risks of female genital mutilation)

FGM also affects the development and progress of any nation, women occupy a greater percentage or part of humanity and whatever affects their wellbeing and development, also affects the development and progress of any nation. This therefore has made the United Nations see Female genital mutilation as an issue since 1948 within the context of the universal declaration of human rights and it was seen as a harmful tradition practice in the 70 s and 80 s, during the United Nation's year for women 1975-1989 [23]. The Universal Declaration of Human Rights which was adopted by the United Nations General Assembly in 1948 was translated into human rights law by two general covenants, both adopted in 1966. These are the International Covenant on Civil and Political Rights (ICCPR) and the International Covenant on Economic, Social and Cultural Rights (ICESCR). These Covenants prohibit discrimination on the grounds of sex and emphasizes the need for the respect of the rights of persons and for the promotion and protection of health.

According to Comhairle shlainte na mBan (2018) violence against women remains a significant problem in all societies and FGM is one of the most severe manifestations. FGM is a harmful traditional practice and a form of violence that directly infringes upon women's (and children's) rights to physical, psychological and social health.

\section{Principle of Autonomy/Totality and Integrity}

This principle specifies that one must act always in such a way as to acknowledge a person's freedom over his/her actions or physical body.

In this regard, the WHO states: "health professionals who perform FGM are violating girls' and women's right to life, right to physical integrity and right to health. They are also violating the fundamental ethical principle: do no harm" (WHO, 2010).

\section{Principle of Avoidance Harm: "do not harm others"}

Although this principle is a negative precept, in its positive consideration, it is principle founded on most natural law theories to advance the preservation of the species. The first principle of natural law, is the law of self-preservation: every being tends by its nature to persist in being. Harm would therefore consist in all manners of threats, injury and challenges to the well-being of persons. Harm includes physical, sexual, emotional, psychological, spiritual and political 
impairment or injury done to the person to diminish his or her capabilities in those areas in (Igboanusi, 2009) John Stuart Mill (1859) gives a very elaborate presentation of this principle thus: The only principle for which power can be rightfully exercised over any member of a civilized community, against his will, is to prevent harm to others. His own good, either physical or moral, is not a sufficient warrant.

It is now internationally accepted that FGM is a harmful cultural practice and an act of violence against the physical and emotional integrity of women and girl-children, wherever and however it occurs. In other words, the practice of FGM as a cultural practice represents a form of violence and a cause of harm to women:

The term "violence against women" means any act of gender-based violence that results in, or is likely to result in, physical, sexual or psychological harm or suffering to women, including threats of such acts, coercion or arbitrary deprivation of liberty, whether occurring in public or in private life ... [including] physical, sexual and psychological violence occurring in the family, including battering, sexual abuse of female children in the household, dowry-related violence, marital rape, female genital mutilation and other traditional practices harmful to women ... (Onuh et al., 2006).

The bouquet of harmful consequences of FGM can be divided in short term and long term consequences. Short term consequences include pain, risk of haemorrhage, shock, sepsis, inability to urinate, infection, damage to other organs, dislocation and fracture of bones due to struggle while being restrained, psychological trauma and death. Long term consequences can be divided into three main areas: gynaecological, obstetric and psychological. Long term gynaecological complications include infection, inflammatory disease, fistulae, vaginal infections, menorrhagia, recurrent abscess formation, infertility, painful sexual intercourse, obstructed menstrual flow, difficulty passing urine, urinary tract infection, vulvar abscess, chronic pelvic infection, incontinence. The effect of such harm and violence on the physical and mental integrity of women is to deprive them of the equal enjoyment, exercise and knowledge of human rights and fundamental freedoms. While this comment addresses mainly actual or threatened violence the underlying consequences of these forms of gender-based violence help to maintain women in subordinate roles and contribute to their low level of political participation and to their lower level of education, skills, and work opportunities.

Additionally, The Convention on the Elimination of All Forms of Discrimination against Women (CEDAW, 1992), adopted General Recommendation No. 19, concerning violence against women. The Committee first expanded upon the Convention's Article 1 definition of discrimination against women by explaining that discrimination includes gender-based violence. According to CEDAW, gender-based violence is violence directed against a woman "because she is a woman or that affects women disproportionately," including acts that "inflict 
physical, mental or sexual harm or suffering ... and other deprivations of liberty. These include the right not to be subject to torture or cruel, inhuman or degrading treatment or punishment and the right to the highest standard attainable of physical and mental health." The CEDAW states that traditional attitudes by which women are regarded as subordinate to men or as having stereotyped roles perpetuate widespread practices involving violence or coercion, such as female circumcision. Such prejudices and practices may justify gender-based violence as a form of protection or control of women.

\section{Conclusion and Recommendations}

From the above analysis, exposition and explanations, it is evident that FGM in any form is recognized internationally as a gross violation of human rights of girls and women. The research conducted in Ebonyi state also corroborates the fact and conviction that FGM is harmful and has negative effects on women, including and especially in their marriages. As part of the contribution of this research, it is therefore pertinent that the following recommendations be made as a contribution to the protection of women in the contemporary global world culture.

Education, Advocacy in Human Rights Protection

Some of the recommendation necessary to curb this obnoxious practice include: education and advocacy for human rights. The importance of protecting human rights in communities and the empowerment of girls in relation to their own development must be accepted. Change is also more likely when the community priorities are addressed and trust is established. The elimination of this obnoxious practice is embraced as one of the targets of Sustainable Development Goals (SDGs) (which is the elimination of all harmful practices including female genital cutting by the year 2030).

The Media play a major role in the eradication of FGM by helping to clarify doubts and misconceptions about it as well as health promotion and FGM eradication programmes. There are different methods of learning about FGM that include television, radio, newspapers, community meetings, discussions with family members or friends, and mosque or church sermons.

Proper, and value-based education is the important key to the elimination of FGM. Also, public education as well as enlightenment programme is vital in producing behaviour change, and is essential to the success of the campaign to end FGM. Education about FGM prevention should be encouraged in schools. Also, reproduction and FGM-related problems should be integrated into science; biology and hygiene lessons; personal, social and gender education; and religious teachings.

Nurses, midwives and doctors, when they are themselves fully aware of FGM and its implications, can facilitate and aid teachers with such education. Medical education must be complemented with adequate training in moral principles [medical ethics] both during initial training and in ongoing professional devel- 
opment, as many nurses and midwives are ill-prepared to deal with FGM at the level of prevention, management and counselling.

Advocacy also means collaboration with public, private and non-governmental stakeholders. In order to develop strong educational strategies, there is a need for collaboration between government bodies, private sector, non-governmental organizations and research institutions, including biomedical and social science researchers who have linkages to relevant communities.

Also, finding alternative sources of income for FGM practitioners; economic and social empowerment for women; the promotion of alternative rites of passage; group discussions and media campaigns aimed at raising awareness; promoting the abandonment of FGM as part of a "development package" that includes a reduction of poverty and of inequities and inequalities between the sexes; and an increase in access to education and health services

Furthermore, the government has given more emphasis on the eradication harmful traditional practice and mandated regional bureaus to have materials/documents, text books and others that discourages harmful practices including FGM in primary school curricula.

Legal Recourse: So far, in many societies, few laws introduce protection measures for girls at risk and FGM prevention measures. The new social context implies greater pressure as FGM is punishable by law. Over the years new attitudes are adopted that contribute to the eradication of FGM. The empowerment of women and girls is also a large factor that contributes to the elimination of FGM. Measures ought to be put in place to ensure that the legislation that punishes FGM do not run the risk of promoting the practice of FGM secretly.

The need for enforcement of extant laws and regulations cannot be overemphasized in order to provide enough deterrence for those who may want to continue along the lines of this obnoxious practice.

\section{Conflicts of Interest}

The authors declare no conflicts of interest regarding the publication of this paper.

\section{References}

Althaus, F. A. (1997). Female Circumcision: Rite of Passage or Violation of Rights? International Family Planning Perspectives, 23, 130-133.

https://www.guttmacher.org/journals/ipsrh/1997/09/female-circumcision-rite-passageor-violation-rights

https://doi.org/10.2307/2950769

Andarge, M. Y. (2014). The Difficulties of Ending Female Genital Mutilation: Case of Afar Pastoral Community in Ethiopia.

https://www.ohchr.org/Documents/Issues/Women/WRGS/FGM/NGOs/ActionForInte gratedSustainableDevelopmentAssociation.pdf

Berggren, V., Musa Ahmed, S., Hernlund, Y., Johansson, E., Habbani, B., \& Edberg, A. K. (2006). Being Victims or Beneficiaries? Perspectives on Female Genital Cutting and Reinfibulation in Sudan. African Journal of Reproductive Health, 10, 24-36. 


\section{https://doi.org/10.2307/30032456}

Centre for Reproductive Right (2006). Female Genital Mutilation. New York: Walls. http://www.reproductiverights.org/sites/default/files/documents/FGM final.pdf

Crossette, B. (1995). Female Genital Mutilation by Immigrants Is Becoming Causing Concern in the US. New York International. https://www.nytimes.com/1995/12/10/world/female-genital-mutilation-by-immigrants -is-becoming-cause-for-concern-in-the-us.html

Fisaha, K. G. (2016). Female Genital Mutilation: A Violation of Human Right. Journal of Political Science and Public Affairs, 4, 2.

https://www.longdom.org/open-access/female-genital-mutilation-a-violation-of-huma n-rights-2332-0761-1000198.pdf

Hrvatin, I., \& Šćepanović, D. (2018). Female Genital Mutilation-Recent Literature Review. Challenges of the Future, 3, 90-102.

Igboanusi, E. (2009). Applied Ethics. Owerri: Living Flames Resources.

Igboanusi, E. (2011). Special Themes in Ethics. Owerri: Living Flames Resources.

Macionis, J. J. (2005). Sociology. Upper Saddle River, NJ: Prentice Hall.

Mberu, B. U. (2018). Female Genital Mutilation/Cutting in Nigeria: A Scoping Review. https://www.popcouncil.org/uploads/pdfs/2017RH FGMC-NigeriaScopingReview.pdf https://doi.org/10.31899/rh7.1023

Mill, J. S. (1859). On Liberty. In Three Essays: On Liberty, Representative Government, the Subjection of Women. Oxford: Oxford University Press.

Mustafa, A. Z. (1966). Female Circumcision and Infibulation in Sudan. Journal of Obstetrics and Gynaecology of the British Commonwealth, 73, 302-306. https://doi.org/10.1111/j.1471-0528.1966.tb05163.x

Odimegwu, C., Okemgbo, C., \& Luqman, B. (1998). Female Genital Mutilation in Nigeria: What Do Adult and Adolescent Men Know? Journal of the Nigerian Anthropological and Sociological Association, 1-2, 97-108.

Okeke, T. C., Anyaehie, U. S. B., \& Ezenyeaka, C. C. K. (2018). An Overview of Female Genital Mutilation in Nigeria. Annals of Medical and Health Sciences Research, 2, 70-73.

Onuh, S. O., Igberase, G. O., Umeora, J. O. U., Okogbenin, S. A., Otoide, V. O., \& Gharoro, E. P. (2006). Female Genital Mutilation: Knowledge, Attitude and Practice among Nurses. Journal of the National Medical Association, 98, 409-414.

Ossai, E., Aniwada, E. C., \& Nwobi, E. A. (2018). Female Genital Cutting: Issues and Perspectives. Journal of Gynecology and Perspectives, 1, Article 1004.

https://scienceforecastoa.com/Articles/JGOF-V1-E1-1004.pdf

Ukhun, C. E. (2002). On the Moral Basis of Clitoridectomy in Africa. In Critical Gender Discourse in Africa (pp. 45-58). Ibadan: Hope.

UN Committee on the Elimination of Discrimination against Women (CEDAW) (1992). CEDA W General Recommendation No. 19: Violence against Women. https://www.refworld.org/docid/52d920c54.html

WHO (1999). Female Genital Mutilation Programmes to Date: What Works and What Doesn't: A Review. http://apps.who.int/iris/bitstream/10665/65857/1/WHO CHS WMH 99.5.pdf

WHO (2010). Global Strategy to Stop Health-Care Providers from Performing Female Genital Mutilation: UNAIDS, UNDP, UNFPA, UNICEF, UNHCR, UNIFEM, WHO, FIGO, ICN, IOM, WCPT, WMA, MWIA. 
https://apps.who.int/iris/bitstream/handle/10665/70264/WHO RHR 10.9 eng.pdf;jses sionid $=$ CCAE5952B568B51FB59C1F23AB5D92D4? sequence $=1$

Yoder, P. S., \& Khan, S. (2008). Numbers of Women Circumcised in Africa: The Production of a Total. Calverton: Macro International Inc.

https://dhsprogram.com/pubs/pdf/WP39/WP39.pdf 